\title{
DOI 10.26886/2520-7474.6(26)2017.11
}

UDC 82-09(477) Куліш

SPECIFICITY OF AUTHOR'S SELF-EXPRESSION IN THE AUTOBIOGRAPHICAL TRILOGY PANTELEIMON KULISH

"MEMORIES OF CHILDHOOD"

\section{K. Mazurik}

National Pedagogical Dragomanov University, Ukraine, Kyiv

The article is devoted to the study of the specifics of the author's selfexpression in the autobiographical trilogy of Panteleimon Kulish "Memories of Childhood", the study of the main forms, ways, means and techniques of the author's "I" presentation in the texts. Hiding under the mask of a fictitious name, the author seeks to personally represent his world, selects the most significant fragments of it and gives them a special substance and forms, in accordance with his own vision, which is formed by his mind and feelings.

It is established that in the trilogy of the Ego the author is represented by various forms of the "I" - the author, the narrator and the hero, the characters and individual biographical facts of which are very close to each other, but not identical, fulfill simultaneously the meaning-forming and structure-forming functions.

Key words: Panteleimon Kulish, the image of the author, self-author, autobiography, autobiographical, ego-literature, autobiographical text.

Мазурик К. В. Специфріка авторського самовираження 6 автобіографрічній трилогії Пантелеймона Куліша «Воспоминания детства» / Національний педагогічний університет імені М. П. Драгоманова, Україна, Київ

Стаття присвячена дослідженню специфріки авторського самовираження в автобіографрічній трилогії Пантелеймона Куліша 
«Воспоминания детства», вивченню основних фрорм, способів, засобів та прийомів презентації «Я» автора у текстах. Ховаючись під маскою вигаданого імені, автор прагне особисто представити свій світ, виділяє найбільш значущі його фрагменти і надає їм особливої субстанції і фрорми, відповідно до власного бачення, яке фрормується його розумом і почуттями.

Встановлено, що Его автора у трилогї презентоване різними формами «Я» - автора, оповідача та героя, характери й окремі біографрічні фракти яких дуже близькі між собою, але не тотожні, виконують одночасно змістотворчі і структуроутворюючі функції.

Ключові слова: Пантелеймон Куліш, образ автора, самовираження автора, автобіографрія, его-література, автобіографрічний текст.

Вступ. Проблема репрезентації образу «Я» автора в творах автобіографрічних жанрів у сучасному літературознавстві $€$ однією із актуальних. В українській науці питання вираження та співвіднесення «Я» автора та героя у еголітературних творах, лише в XXI ст. привернули увагу вітчизняних дослідників. Особливості авторського самовияву, авторської самототожності у художньому тексті XX ст. стали об’єктом вивчення Т. Черкашиної, І. Скнаріної, А. Цяпи та ін., однак автобіографріка XIX ст., зокрема еголітературна творчість Пантелеймона Куліша, за винятком поодиноких студій В. Петрова, Л. Юровської, Ю. Мариненка, І. Бойцун, Ю. Бондаря, досі залишається малодослідженою, хоча саме цей письменник варифрікував жанр художньої автобіографії та автобіографрічної повісті в українській літературі.

Формулювання мети статті та завдань. Метою статті $\epsilon$ дослідження специфіки авторського самовираження в автобіографічній 
трилогії «Воспоминания детства» П. Куліша, вивчення основних фоор, способів, засобів та прийомів презентації «Я» автора у текстах.

Виклад основного матеріалу статті. Структуротворчим центром автобіографічного твору $є$ автор та його образ, тому узагальнений образ «Я» митця певної епохи став предметом аналізу в більшості наукових студій, присвячених науковому осмисленню феномена автобіографріки як літератури non-fiction, адже центром будь-якого автобіографрічного тексту $€$ образ «Я» (Гінзбург). Дослідження проблеми репрезентації «Я» митця в автобіографрічних текстах трилогії «Воспоминания детства» П.Куліша здійснено з використанням біографрічного, психоаналітичного, порівняльно-історичного та інтертекстуального методів.

Важливим складником автобіографічного дискурсу Пантелеймона Куліша $€$ автобіографрічна трилогія «Воспоминания детства», до якої увійшли повісті «Яков Яколевич», «Феклуша» «Ульяна Терентьевна».

Написана у 50-х рр. XIX ст., трилогія відображає основні настрої та естетичні пріоритети автора чи не найскладнішої доби в його житті: страшне душевне потрясіння після розгрому Кирило-Мефодївського Товариства, крах кар'єрних сподівань, заборона творчої самореалізації, та найголовніше - відчуженість від своєї Батьківщини, самотність, неможливість реалізації важливої мети життя: консолідації національної інтелігенції задля великої праці на ниві культури. Втрата змоги друкувати україномовні твори через політичні утиски та водночас бажання відновити власне реноме в середовищі української та російської еліти, повернутися в літературу, спробувати власні сили після вимушеної перерви - ось основні причини, які спонукають П.Куліша до пошуків способів обійти особисту заборону російського царя на право друкуватися. 3 цією метою письменник перейде на російську мову, порушуючи здебільшого нейтральну тематику в руслі 
соціально-побутової чи психологічної проблематики, на якій позначилося захоплення автором популярних у той час руссоїстських $\square$ ідей, що й реалізується в автобіографічних повістях митця.

Естетична природа стилю епіки П.Куліша визначає особливості репрезентації в них авторського «Я». Творчість цієї доби представляє зміни естетичних симпатій письменника: крім «романтичної схильности до зображення гіпертрофованих почуттів та $\square$ ідеалізації характерів» [1, с. 121], у повістях П.Куліша відчутні впливи натуральної школи (Є. Гребінка, М. Гоголь) та діккенсівського реалізму. Попри те, що основа творів автобіографічна, вони містять значну частину художнього домислу, оскільки письменник творчо переосмислює свій життєвий досвід і намагається використати його для реалізації власного ідейного замислу.

Автобіографічна трилогія «Воспоминания детства» - це осмислення першопочатків свого життя в найкритичніший його момент, тому звернення автора до свого дитинства як до початкового періоду буття, часу, що відкриває собою життя людини, - це спроба осмислити витоки і джерела фрормування себе як людини, як творчої особистості, представити дитинство з позиції його цінності для дорослої людини, та найголовніше - відновити пам'ять про свій рід, плем'я, народ, культуру, традиції, оту сакральність минулого, трансцедентно передану йому предками, що швидко зникає із життя в новому часі. Водночас спогади про дитинство пов'язуються 3 уявленнями про втрачений рай (особливо в часи заслання, коли ностальгія за дитинством виявлялася адекватною ностальгії за батьківщиною), про неможливість повернення в той час і простір, з яким пов'язуються уявлення про мир, спокій і щастя: «Мир представлялся мне светлою областью, в которой все одинаково прекрасное тотчас взаимно чует себя и спешит сблизиться. 
Душа моя была тогда открыта доверчиво любви и дружбе, как цветок солнечному сиянию» [2, с. 253].

У трилогії вперше в П.Куліша досить чітко оприявнюється його християнізована версія неоплатонізму. У цьому сенсі спогади про дитинство - це ще й данина письменника українській старосвіччині, яку він бачить як основу духовно-культурної традиції української нації 3 притаманним їй етико-релігійним трактуванням сенсу людського життя. Власне, на цих духовних основах неоплатоніст Куліш і зосередить свою оповідь. Саме тому центром його самовираження у автобіографріці загалом, зокрема й у цій трилогії, $є$ духовне наповнення людського «Я», котре «осмислюється К. (Кулішем - К.М.) в єдності 3 історичною долею спільноти, до духу якої внутрішньо причетна людська одиниця» [3, с. 112].

Повісті «Яков Яковлевич», «Феклуша», «Ульяна Теретьевна» об'єднує в трилогію низка ідентичних жанротворчих рис автобіографрічного твору: єдність автора, оповідача (Ніколай М.) та героя (хлопчик Ніколаша), які представляють особистість у різні роки та утілюють різні періоди життя самого автора, оповідна фрорма, специфічний хронотоп, наративні особливості та стиль викладу тощо.

Першою відповідно до хронології відображених подій із життя П. Куліша, які стають художньою канвою історії маленького хлопчина Ніколаші - центрального образу трилогії, вважаємо повість «Ульяна Терентьевна». Цей твір представляє перший етап творення власне авторської ідентичності, яка в осмисленні раннього дитинства зазнає коригуванння до простої і ясної ідеї дитинства як раю, «дитинства як благого місця, де нема ні страждань, ні мирської суєти і де можна заховатися від невблаганного часу. Таке розуміння дитинства як раю і дитини як ангела, як слушно підкреслила І.Старовойт, «дає змогу автобіографові принаймні щось протиставити цинічному сучасному i, 
наслідуючи Гесіода, розмістити золотий вік не попереду, а позаду себе» $[4$, с. 179$]$.

Оповідь у трилогії ведеться від першої особи - Ніколая М. (містифікованого героя, за ім'ям якого ховається автор, оскільки йому заборонено друкуватися), котрий утілює авторську позицію, його ставлення до самих подій та їх учасників. Разом із тим така форма викладу не дає підстав повністю ототожнювати оповідача з автором, самим Кулішем. Хоча в оповідачеві за деякими рисами можна впізнати автора, однак між ними є і суттєві розбіжності, як біографрічного, так і психологічного характеру. Тож в контексті проблеми репрезентації авторського «Я» в трилогії П. Куліша чітко виділяємо три фрорми самовираження, які представляють три образи: оповідача (Ніколая М.), оповідача в дитинстві (Ніколаші) та самого П. Куліша, окремі риси якого угадуються в героях.

Оповідач трилогії, містифрікує не лише оповідача, але й час, наполегливо підкреслюючи, що від описуваних подій його відділяє відстань більше ніж у сорок років, але на момент написання першої повісті («Яков Яковлевич», 1852 р.) самому Кулішеві виповнилося тільки тридцять три. Тож оповідач постає як письменник, людина солідного віку, яка з висоти свого досвіду згадує минуле, зупиняючись на подіях дитинства, отроцтва та ранньої юності, що закарбувалися в пам'яті як найкращі в його житті. I хоча подекуди вони затьмарювалися трагічними моментами (смертями Феклуші та Якова Яковича, трагедіями Померанцева, Софії Карлівни, сімейною драмою Уляни Терентівни), усе ж для нього вони залишаються щасливим періодом свіжого і чистого сприйняття життя. 3 іншого боку, автор - доволі молодий чоловік, мета якого - через спогади різних періодів свого життя відтворити побут та морально-етичну атмосфреру буття різних соціальних груп українців, котрі на початок XIX ст. з титульної нації 
перетворилися на провінціалів імперії, «великих невдах, великих страждальців з їх безпросвітним життям, дріб'язковими клопотами» [5, с. 175]. Третім «я» в повістях постає образ оповідача, яким він бачиться собі сорок років тому, - хлопця Ніколаші в дитинстві та отроцтві.

Оповідач багато в чому нагадує самого П.Куліша: подібністю деталей біографії, професією (він також є письменником), деякими психологічними особливостями. Читач крізь призму оповідача бачить самого автора, і в силу значної їх подібності може сприймати трилогію навіть як мемуарні записки. Саме автобіографіка в певній мірі прояснює своєрідність характеру П.Куліша, його дивакуватості, особливості стосунків із жінками, психологічну мотивацію вчинків митця, агресивність, зокрема до думки опонента, специфічну парадоксальність творчої особистості. Еголітература здатна привідкрити таємниці «Я» письменника, його несвідоме та архетипне.

Загальний інтелектуальний образ оповідача складається в уяві читача завдяки згадкам про явища світової культури, які почасти трапляються в його творах. Так, наприклад, про батька він каже, що завдяки тому, що той знав «первую часть арифметики и всего Державина наизусть», был между соседями Аристотелем» [2, с. 244]; від Дениса Ніколаша слухав історії про Олександра Македонського; Уляні Терентівні цитував уривки з Державіна; в помісті Мужиловської пізнав творчість Шиллер; поемами і віршами Пушкіна й Жуковського школярі списували зошити і вчили їх напам'ять. 3 часом, уже дорослий письменник постійно покликається на образи класичного мистецтва.

У повісті «Ульяна Терентьевна» перед читачем розкриваються причини та історія формування у майбутнього письменника комплексу Едіпа: гіпертрофроване захоплення жінкою, котра в певний момент сприймалася маленьким хлопчиком як ідеал жінки; відчуття 
задоволення, котре входить у протиріччя із реальним станом життя, почуття вини тощо. Комплекс цей у випадку П.Куліша мав і своє чисто життєве пояснення - жорсткість батька у ставленні до свого сина. Про свій страх перед батьком він згадуватиме у багатьох творах: окрім трилогії «Воспоминания детства», про авторитарність батька він напише в автобіографії «Жизнь Куліша» та романі «Владимирия».

Сімейними обставинами сам автор пояснює відлюдькуватість та почуття відчуженості маленького героя Ніколаші, його несхожість на інших дітей. Найвагоміші причини - рання втрата матері, нестача материної ласки, з одного боку, та близьке спілкування з жінкою іншого соціального і духовного складу, ніж його сім'я, з Уляною Терентівною, що через власні сімейні обставини поселилися по сусідству від батьківського обійстя: «Сказать правду, я не очень был привязан к родительскому дому, - не потому, чтоб я был равнодушен к месту своих первых радостей, не потому, чтобы мне не было в нем привольно, но потому что у меня не было матери» [2, с. 260]. Більше уваги матері автор присвятив в автобіографії «Жизнь Куліша», визнавши, що вона справила значний вплив на формування його любові до українських традицій. Отже, ще з раннього дитинства в ньому пробуджується і визріває своєрідна дихотомія, два протилежні уявлення про світ і красу: розуміння довершеності морально-етичного комплексу народного життя, з одного боку, i прагнення до аристократичної витонченості, з іншого. Ця постійна опозиція вплинула на розуміння соціальних проблем і призначення мистецтва. Звідси одна з основних тенденцій життєвого і творчого шляху Куліша, оприявлена в його автобіографічних творах, яка неодноразово буде поміченою дослідниками його творчості, - це боротьба його аристократизму з любов'ю до народної української стихії, того аполонівського та діонісійського начал, які не могли знайти рівноваги ні 
в характері, ні в творчості, ні в житті самого письменника. У певний час одна з цих тенденцій посилювалася, витісняючи іншу, фрормуючи унікальний візерунок ідейної спрямованості Кулішевої творчості. Повість «Ульяна Терентьевна» представляє авторську концепцію формування його естетико-інтелектуальної аристократичності, яку в ньому відкрила в дитинстві Уляна Терентівна Мужиловська, тому матері в повісті, як представникові народнопоетичної стихії, він відводить менше уваги.

Цікавим аспектом у фрормуванні майбутнього письменника $є$ його стосунки з батьком. У повістях і автобіографрії ці стосунки батька 3 сином представлені дещо по-різному: маленького Ніколаші з Іваном Карповичем та Пантелеймона з батьком Олександром. У повістях батько оповідача постає людиною, котра суттєво інтелектуально відрізняється від свого оточення (читав напам'ять Державіна), хоч і досить суворою, але такою, що своєрідно любить свого сина, не шкодує для нього та його навчання коштів, до якої Ніколаша може звернутися зі своїми труднощами. Натомість із автобіографії стає відомо, що Куліш боявся свого батька і батьківської уваги йому не вистачало. Саме зазначена емоційна атмосфрера (побоювання батька в Куліша та відсутність цього страху в Ніколаші) і $\epsilon$ наріжним каменем розрізнення стосунків персонажів у повісті та їх прототипів.

3 ранньою втратою матері, відсутністю тісного емоційного зв'язку з батьком пов'язує оповідач власну чутливість і сприйняливість до навколишнього світу, до людських переживань і горя: «...в одинокой своей жизни дома, скучному училищному быту и отсутствию материнской любви приписываю вообще раннее развитие во мне симпатий ко всему, что манит сердце» [2, с. 270].

Для Куліша 50-ті й 60-ті роки ознаменовані черговою зміною пріоритетів громадянської і світоглядної позицій. Можливо, саме тому 
замість теплоти, з якою описана старосвітська атмосфера, у якій зростав малий Панюша, описаній у «Жизні Куліша», у «Воспоминаниях детства» оповідач говорить про неї з певною погордою: «Соседи моего отца были прямые потомки тех козаков, которые приобрев права дворянства, не усвоили себе привычек образованной жизни. Они какбудто еще только вчера скинули старосветские жупаны и надели запоздалого покроя сюртуки. Добрый народ был, но скучный до крайости. Немногие бы пожелали между таким народом родиться» [2, с. 244]. Якщо пізніше в «Жизні Куліша» письменник наголошуватиме на своєму зв'язку з козацьким родом Гладких та говоритиме про старосвіччину з приязню, то у «Воспоминаниях детства» оповідач дещо зневажливо ставиться до рідного середовища свідомий своєї вищості. Однак представлення рідного простору в такому непривабливому ракурсі, на нашу думку, викликане історикополітичними причинами: утисками української культури, забороною українського слова тощо. Замилування національною культурною стихією призвело б до цензурних заборон друкуватися, а Куліш якраз прагнув публікації.

Ніколаша постає в трилогії як хлопець вразливий, наділений від природи багатою уявою: «Удивительные вещи развивало в детстве мое воображение из самых ничтожных обстоятельств. Все, что я слышал, облекалось для меня в картины; часто одно слово становилось для меня завязкою целой истории; довольно мне было провести одну черту в характере человека, уже я сам себе его дорисовывал» [2, с. 245]. Через те кожне враження, кожна розмова породжували в його уяві яскраву послідовність образів.

Автор постійно підкреслює вроджений артистизм і вразливість хлопця, котрі часто підсилюються описом несподівано екзальтованої реакції дитини на красу: чи це музика, чи красивий голос, чи опис 
картини, чи пейзаж за вікном - все викликає неймовірні внутрішні емоції хлопчика: «Я онемел и окаменел; потом начал плакать, и что только когда-либо запало в мою душу нежного, трогательного, возвышенного, все в ней ожило и заговорило. Я плакал, припоминая голос моей матери, который более не отзовется ко мне из темной могилы; я плакал, припоминая песни соловья, который каждую весну пел у меня под окном, пока я не был отправлен в училище; я плакал о Софье Карловне и о Феклуше, о Якове Яковлевиче, угаснувшем, можно сказать, при первом звуке любви, в первый миг уверования, что его любят; я плакал от восторга, думая об Ульяне Терентьевне и об ее чудной материнской любви ко мне; я плакал наконец сам не зная от чего» [2, с. 301-302].

Говорячи про себе, автор підкреслює, що рано усвідомив свою виключність, у якій була переконана вся його родина і про яку говоритиме він сам і в автобіографії, і в щоденниках. Він також наголошує на тому, що в дитинстві був значно доросліший за свій вік: «Я в детстве не был ребенком: я чувствовал, радовался и страдал, как взрослый» [2, с.258]. Варто зазначити, що й манера спілкування Ніколаші не відрізняється від манери спілкування дорослих: у ній не відображені вікові особливості 13-річного хлопця. Значною мірою це можна також пов'язати із тим, що оповідач повністю переноситься у час зображуваних подій і говорить зі співрозмовниками так, як би говорив тепер.

Образ себе у дитинстві оповідач творить переважно за рахунок прямої самохарактеристики, зрідка надає право характеризувати себе іншим особам. Крім того, значну роль відіграє зображення переживань Ніколаші, його уяви, вчинків, стосунків з іншими людьми. Однак варто відзначити, що перед читачем постає досить ідеалізований образ 13річного хлопця, і навіть незначні вади, про які згадується у творах (як- 
то: дитячі пустощі в школі чи нездібність до деяких шкільних предметів), сприймаються швидше як милі риси чутливої і артистичної дитячої натури.

Отже, Ніколаша, прототипом якого став сам Пантелеймон Куліш, уже в дитинстві виявляє всі ті риси, що стали базовими у становленні його як письменника: увага до інших людей, до деталей їх життя, глибоке співпереживання, багата уява, здібності до декламування, малювання тощо - усе це мало свідчити про артистичну натуру хлопця.

Протиставляючи себе тодішнього, тринадцятирічного хлопця, і теперішнього, дорослішого на сорок років (як каже оповідач у повістях), оповідач згадує неодноразово про зміну в поглядах і світовідчутті, яких він зазнав із часом: «Я не ведал тогда этой тягостной осторожности, которая связывает нам язык в самом восторженном нашем состоянии; я не знал еще, что притворство в житейских сношениях с людьми есть непременное условие нашего спокойствия и безопасности!» [2, с. 253]. Тут уже виявляється «Я» Куліша-автора, його гіркота та розчарування пов'язані із засланням до Тули, постійна потреба прикидатися у тепер уже чужому життєвому просторі, стежити за власними вчинками і словами, щоб знову не втрапити у немилість. Отже, роки дитинства, коли він ще міг вільно відчувати і висловлювати свої переживання, вважає оповідач найкращими у своєму житті, що підкреслить пізніше автобіографії: «...Детство мое не потеряло для меня той умилитительной прелести, которую - хотя смутно- сознавал и сам Яков Яковлевич. За свежесть впечатлений, за восприимчивость души, за сладостное ощущение бытия в ту эпоху жизни я бесконечно благодарен своему Создателю» [2, с.258].

Виявляються у повістях побіжно і політичні погляди автора. Так, описуючи випадок, коли декламував у дитинстві уривок з Державіна для Уляни Терентівни, оповідач зауважує: «... а я потому вспомнил эти 
стихи, что в моей новой знакомке было что-то Екатерининское. Я смотрел на нее, как на величайшую женщину в мире, и не было меры преданности, которую я к ней чувствовал» [2, с. 279]. Таке палке вираження прихильності режиму, яке мало пасувало 13-річному хлопчикові (який навряд чи міг так глибоко «розуміти» i «захоплюватися» царицею), значною мірою зумовлено тим, що в 1852 році (коли з'явилася повість) Куліш тільки-но повернувся із заслання до Тули. У цей період, як відзначає Є.Нахлік, «опальний письменник силкувався визначитися в нових умовах, що в них $\square$ неждано-негадано потрапив, а тому хотів засвідчити свою лояльність до панівного $\square$ режиму й завдяки цьому зайняти помітне місце в легальному літературному $\square$ процесі. Як ніколи до й після цього, він писав з осторогою, оглядаючись на тодішні $\square$ цензурні вимоги, позаяк зобов'язаний був подавати свої твори на рецензію до $\square$ III відділення» [6, с.78]. Ця опальність змушувала автора висловлювати в такій формі свою відданість режиму.

Висновки. Тема дитинства має універсальний характер і нерозривно пов'язана з центральними, наскрізними проблемами творчості П. Куліша 50-60-х рр. XIX ст.: роздумами про долю, про Бога, про батьківщину, про народ, про природу, про себе. Автобіографічний текст - це завжди презентація автора себе через різні фрорми представлення: констатуюча (через хронологічно послідовну історію життя чи різні фракти з життя персонажа), психологічно-емоційна (характеризує емоційний стан героя, його почуття і настрої).

У автобіографічній трилогії «Воспоминания детства» авторське «Я» репрезентоване в образах оповідача у його «тоді» (13-річному віці) й «тепер» (40 років по тому) та самого автора (33-річного чоловіка), характери й окремі біографічні фракти яких дуже близькі між собою, але не тотожні. Ці відмінності виявляються на різних рівнях: віковому, 
подієвому, психологічному тощо. «Я» дитини - хлопчика «Ніколаші» презентує формування дуалістичного світогляду самого П. Куліша, складну боротьбу діонісійського та аполонівського начал і в характері самого митця, і в його поглядах, і в його житті. Ховаючись під маскою вигаданого імені, П.Куліш представляє свій особистий світ, який формується його розумом, відчуттями і почуттями, акцентуючи на найбільш значущих для нього фрагментах життя. Водночас проявляються і ті риси, що виявляють психологічний стан Куліша на момент написання повістей, його Его, його «Я», зокрема у моментах невпевненості у майбутньому, недовіри до оточення, що виникли під впливом нещодавно пережитого заслання.

Его автора презентоване різними фрормами «Я», виконує одночасно низку різноманітних змістотворчих і структуроутворюючих функцій, а це проблема, котра потребує подальшого детального та глибокого осмислення.

\section{תimepamypa:}

1. Нахлік Є. Пантелеймон Куліш: Особистість, письменник, мислитель: наукова монографрія: у 2 m. / Євген Нахлік - K.: Український письменник, 2007. - Т.2: Світогляд i творчість Пантелеймона Куліша. - 462 с.

2. Повести П. А. Кулиша в 4 m. / П. А Кулиш. - Т. 3: Воспоминания demства. - С.-Пб, 1860. - 430 c.

3. Філософрська думка в Україні: Біобібліогр. словник / Авт. кол.: В. С. Горський, М. Л. Ткачук, В. М. Нічик та ін. - К.: Унів. вид-во Пульсари, 2002. - 244 c.

4. Старовойт I. Aвтобіографрія дитинства / Ірина Старовойт // Вісник Львів. ун-ту. Сер. фрілол.- Вип 33. Ч. І: Львів. ун-т імені І.Франка, 2004. - С. 178-185. 
5. Федченко П. М. Петро Гулак-Артемовський. Євген Гребінка. // Гулак-Артемовський П. Поетичні твори. Гребінка Є. Поетичні твори, повісті та оповідання. / Вст. cm. П. М.Федченко - К.: Наук. думка, 1984. - C. $5-29$.

6. Нахлік Є.. Пантелеймон Куліш: Особистість, письменник, мислитель: наукова монографрія: у 2 m. / Євген Нахлік. - К.: Український письменник, 2007. - Т. 1: Життя Пантелеймона Куліша: наукова біографрія. - 463 с.

\section{References:}

1. Nakhlik Ye. Panteleymon Kulish: Osobystist', pys'mennyk, myslytel' : naukova monohrafiya: u 2 t. / Yevhen Nakhlik - K.: Ukrayins'kyy pys'mennyk, 2007. - T.2 : Svitohlyad i tvorchist' Panteleymona Kulisha. $462 \mathrm{~s}$.

2. Povesty P. A. Kulysha v 4 t. / P. A Kulysh. - T. 3: Vospomynanyya det.stva. - S. $-P b, 1860 .-430$ s.

3. Filosofs'ka dumka v Ukrayini: Biobibliohr. slovnyk / Avt. kol.: V. S. Hors'kyy, M. L. Tkachuk, V. M. Nichyk ta in. - K.: Univ. vyd-vo Pul'sary, 2002. - $244 s$.

4. Starovoyt I. Avtobiohrafiya dytynstva / Iryna Starovoyt // Visnyk L'viv. untu. Ser. filol.- Vyp 33. Ch. I: L'viv. un-t imeni I.Franka, 2004. - S. 178-185.

5. Fedchenko P. M. Petro Hulak-Artemovs'kyy. Yevhen Hrebinka. // HulakArtemovs'kyy P. Poetychni tvory. Hrebinka Ye. Poetychni tvory, povisti ta opovidannya. / Vst. st. P.M.Fedchenko - K.: Nauk. dumka, 1984. - S. 5 29.

6. Nakhlik Ye.. Panteleymon Kulish: Osobystist', pys'mennyk, myslytel': naukova monohrafiya: u 2 t. / Yevhen Nakhlik. - K.: Ukrayins'kyy pys'mennyk, 2007. - T. 1: Zhyttya Panteleymona Kulisha: naukova biohrafiya. $-463 \mathrm{~s}$. 